\title{
A study to measure the impact of privatized industries
}

\author{
Seyed Hossein Miri* and Hamideh Aawani
}

Department of Management, Semnan Branch, Islamic Azad University (IAU), Semnan, Iran

\begin{tabular}{|c|c|}
\hline ART I C L E I N F O & A B S T R A C T \\
\hline $\begin{array}{l}\text { Article history: } \\
\text { Received March 22, } 2012 \\
\text { Received in Revised form } \\
\text { May, 8, } 2012 \\
\text { Accepted } 11 \text { May } 2012 \\
\text { Available online } \\
\text { May } 152012 \\
\text { Keywords: } \\
\text { Privatization } \\
\text { Return on assets } \\
\text { Return on equity }\end{array}$ & $\begin{array}{l}\text { One of the most important issues in privatization is to measure the impact of such decisions on } \\
\text { improving efficiency of governmental organizations. Privatization, in the past, has had both } \\
\text { positive and negative consequences in different countries. Therefore, it is necessary to measure } \\
\text { the impact of privatization in Iran to see the outcome of such decision. In this paper, we present } \\
\text { an empirical study to measure the financial performance of the privatized firms three years } \\
\text { before and three years after privatization happed using pairwise t-student. We use five financial } \\
\text { figures of asset turnover, working capital turnover, return on assets, return on equity and } \\
\text { earnings per share. The results indicate that there was no meaningful relationship between these } \\
\text { financial figures before and after privatization occurred. }\end{array}$ \\
\hline
\end{tabular}

\section{Introduction}

Privatization is one of the most popular methods for reducing the size of governmental activities and reducing their budget. It helps privatized organizations to restructure their structures and to reduce unnecessary activities, which help increase productivity. However, privatization may have some negative consequences when it is not properly implemented. During the past few years, there have been many cases where some privatized firms failed to operate and filed for bankruptcy. Therefore, we need to perform an empirical study to find the reasons for possibly find some remedies. Boubakri et al. (2011) investigated the political factors of residual state ownership for a unique database of 221 privatized corporations operating in 27 emerging countries from year 1980 to year 2001. After controlling for firm-level and other country-level conditions, they reported that the political institutions in place played important role of residual state ownership in newly privatized firms. They also reported that unlike older evidence that political ideology was an important determinant of privatization policies in developed countries, right or left-oriented governments did not behave differently in developing countries. 
Wei and Varela (2003) investigated the relationship between state equity ownership and firm market performance for China's newly privatized firms in 1994 (164 firms), 1995 (175 firms), and 1996 (252 firms). They reported that state ownership had a negative impact on firm value. In their statistical observations, Tobin's Q was convex with in terms of state ownership and newly privatized firms received capital and higher market values, with their increased size paying off based on of stock returns. The impact of international ownership was unpredictable and domestic institutional ownership did not seem to improve performance, possibly because the latter lack proper incentives to positively impact the firm's management. Their results also showed that firm performance was not an important determinant of state ownership, but rather, firm size and its strategic industry status were the main determinants of the state's equity ownership in China's newly privatized companies.

Harper (2002) implemented 453 separate companies where 101 firms privatized, in the first and second waves of Czech voucher privatization. They implemented methodology from previous studies and realized that while the overall influences from privatization were positive, the impacts vary by privatization wave, size, and industry. Companies privatized in the first wave performed worse than business units privatized in the second wave did but they failed to detect ownership concentration or debt as a necessary factor in restructuring the firm.

In Harper's opinions, the results were consistent with two hypotheses. First economic and political structure surrounding the privatization waves played a necessary segment in the success of privatization. Stable environments, both political and economic, helped privatized firms restructure and improved operating performance as well as attracted foreign investors and capital even in less developed countries but in transitional economies undergoing mass privatization in rapidly changing and developing economic and political circumstances hindered business units from restructuring and improving performance following privatization. Harper's results were also consistent with the hypothesis that firms with a longer preparation period prior to privatization, an "implicit seasoning", could have a better chance to improve performance after privatization occurred.

Mathur and Banchuenvijit (2007) examined changes in the financial and operating performance of 103 firms worldwide privatized through public share offerings during 1993-2003 in both emerging markets and developed countries. Their empirical results from the Wilcoxon and proportion exams indicated increases in profitability, capital spending, operating efficiency, output, and dividend payments as well as reduction in leverage and total employment. The results indicated that privatization could improve firm performance in a wide variety of countries, industries, and competitive environments.

Boubakri and Bouslimi (2010) investigated which factors influenced the decision of analysts to follow newly privatized firms as well as the factors, which determine the extent of that following. Contrary to conventional private firms, privatized business units harbor particular uncertainties associated with the government's commitment toward privatization. The first-stage estimation indicated that the decision by analysts to start coverage of newly privatized firms is positively impacted by lower political risk, better information disclosure, better judicial efficiency, and effective extra-legal institutions in the country.

Vogel (2011) explained that the airport business needs a significant amount of capital to accommodate traffic growth and investigated to find an appropriate reply on whether privatized airports earn their cost of capital. Vogel used the necessary data from 2003 to 2009 for a long-term trend analysis, compared the financial performance of ten publicly quoted European airports. The majority of sample airports generated a negative economic value added and reported that trafficinduced investment spending was the single most influential factor.

Boubakri et al. (2008) studied the extent of political connections in newly privatized business units based on a sample of 245 privatized units headquartered in 27 developing and 14 developed countries from year 1980 to year 2002 and reported that 87 firms had a politician or an ex-politician on their 
board of directors. Omran (2004) explained that privatized companies had not exhibit substantial improvement in their performance changes relative to state-owned enterprises (SOEs). They argued the benefits of Egyptian privatization and explained that it could be interpreted to mean that privatization improved the performance of privatized firms, which, in turn, may had had important spillover impacts on SOEs. Ng et al. (2009) investigated the privatization for more recent sample of 4315 privatized Chinese firms during from 1996 to 2003. The results supported the hypothesis of a convex relationship between state ownership and performance showing benefits from strong privatization and state control.

Qi et al. (2000) studied whether the corporate performance of listed Chinese firms was influenced by their shareholding structure using a sample of all firms listed in the Shanghai Stock Exchange (SHSE) from 1991 to 1996. They reported that firm performance was positively associated with the proportion of LP shares but negatively associated with the proportion of shares owned by the state. They also reported that firm performance increases with the degree of relative dominance of LP shares over state shares. In addition, for the subsample of firms, which did not have both state and LP shares, the return on equity (ROE) of firms with LP shares but no state shares is higher than that of firms with state shares but no LP shares by $3.84 \%$, and this difference was statistically significant. They concluded that the ownership structure composition and relative dominance by different classes of shareholders could influence the performance of state-owned enterprise (SOE)-transformed and listed firms.

The proposed study of this paper investigates the impacts of privatization on 17 firms in Iran. The organization of this paper first presents details of our survey in section 2. Section 3 explains details of our results and finally concluding remarks are given in the last to summarize the contribution of the paper.

\section{The proposed study}

The proposed study of this paper gathers five financial figures including asset turnover, working capital turnover, return on assets, return on equity and earnings per share. The purpose of our study was to gather the financial information from all privatized firms but due to limited access to transparent information, we have selected the information from 17 firms in nine different sectors of industry including basic metals (6 firms), machinery (3 firms), auto industry and part makers (2 firms), nonmetal material, electric machinery, chemical industry, transportation, shipping and precision devices. We examine the following general hypothesis,

$\begin{cases}\mu_{1}=\mu_{2} & \text { There is no different between financial performance of the firms before and after privatization. } \\ \mu_{1} \neq \mu_{2} & \text { There is a different between financial performance of the firms before and after privatization. }\end{cases}$

We use two-way t-student tests to examine different hypotheses. Table 1 shows details of our financial ratios used for the proposed study of this paper.

Table 1

Financial ratios for the effects of privatization

\begin{tabular}{llll}
\hline Group & Subgroup & Variable & Formula \\
\hline 1.Operating ratios & 1 & Asset turnover & Total sales/Total assets \\
& 2 & $\begin{array}{l}\text { Working capital } \\
\text { turnover }\end{array}$ & Net Sale/Working Capital \\
\hline 2.Profitability ratios & 1 & Return on assets & Net earnings/Total assets \\
& 2 & $\begin{array}{l}\text { Return on equity } \\
\text { Earnings per share }\end{array}$ & $\begin{array}{l}\text { Net earnings/Total equity } \\
\text { outstanding }\end{array}$ \\
\hline
\end{tabular}


We apply five hypothesis one two-group ratios of 1 and 2 with their subgroup divisions including 1.1, 1.2, 2.1, 2.2 and 2.3 using two-way t-student test and we use significant value (Sig.) to validate the results.

\section{The results}

In this section, we provide t-student values associated with five hypothesis and the results are summarized in Table 2 as follows.

\section{Table 2}

The results of t-student values for the hypotheses

\begin{tabular}{llllllll}
\hline Hypothesis & $\begin{array}{l}\text { Operating } \\
\text { ratios }\end{array}$ & $\begin{array}{l}\text { Asset } \\
\text { turnover }\end{array}$ & $\begin{array}{l}\text { Working capital } \\
\text { turnover }\end{array}$ & $\begin{array}{l}\text { Profitability } \\
\text { ratios }\end{array}$ & $\begin{array}{l}\text { Return on } \\
\text { assets }\end{array}$ & $\begin{array}{l}\text { Return on } \\
\text { equity }\end{array}$ & $\begin{array}{l}\text { Earnings } \\
\text { per share }\end{array}$ \\
\hline t-student & 1.615 & 0.881 & -1.617 & -1.000 & -0.284 & 1.609 & 1.000 \\
\hline Sig. & 0.126 & 0.391 & 0.126 & 0.332 & 0.780 & 0.129 & 0.332 \\
\hline
\end{tabular}

As we can observe from the results of Table 2, none of t-student values represents meaningful value when the level of significance is 5 percent. They are not even meaningful when the level of significance is $10 \%$. Therefore, we can conclude that there has been no change on any financial figures. In other word, if the government wishes to improve financial performances of firms through privatization, this wish never comes true. There are many reasons behind this undesirable outcome of privatization in Iran and we briefly discuss some them in this section.

In the past, when privatization happened successfully and the results of this action come to increase productivity, the government does not appoint management team and the major non-governmental shareholders do this act. As a result, we see some changes on business strategy, which comes with labor reduction, outsourcing, etc. These issues eventually improve financial figures and privatized units could restructure their business units, significantly. Unfortunately, the government holds a major portion of newly privatized firms' outstanding shares and does not let minority shareholders introduce any member of board of directors. As a result, there is not much change on decisions made by older group and as we expect, the performance of the privatized firms would not change.

The other reason is that when government sells a big portion of its shares through stock market, many governmental contracts is also disconnected and newly privatized firms will face with many crises. Another reason to blame is associated with the regulation and rules since some people take part in privatization program by purchasing $30 \%$ of the shares in installment and make the payment by some illegal actions. In fact, there are cases where some people purchased only one-third of a privatized company's outstanding shares and changed the management completely. Next, they pushed the governmental banks to get loans and transferred the loans into other firms. As a result, the privatized firm was responsible to pay loan interest and faced with shortage of cash flow.

There are other cases, where a small group of investors purchased only one-third of a privatized company and stock price was hyped in the stock market. The manipulation on stock price could motivate many novice investors to purchase the share based on the existing rumors on the stock market and within a few weeks, the number of small shareholders increased and the initial investors unloaded their shares into the market. In such circumstances, newly privatized firms did not have good management team and financial performance did not improve, significantly.

There are some other cases where government first privatized some firms and then discontinued its support. For instance, the government subsidizes the raw material specially in offering raw materials from national mines but when the firm is privatized, the new regulation increases raw materials, substantially, which reduces efficiency. 
In summary, we can conclude that there are many reasons, which could be blamed for not reaching privatization financial objectives and there is a need to carefully take into account all these figures and take some necessary actions against them.

\section{Conclusion}

In this paper, we have presented an empirical study to measure the impact of privatization in Iran. We have selected 17 firms from 9 groups of industry and calculated two operating and profitability ratios three years before and three years after privatization happened. The study used the data from year 2004 to 2010 from the documents presented to the official stock market and analyzed the results based on two-way t-student test. The results confirmed that the performance of the privatized firm did not change before and after privatization happened.

We have discussed many reasons, which led to undesirable outcome of privatization in Iran. We have explained that the government did not wish to let private sector completely take the control of the privatized firms and this was one of the major reasons for undesirable financial outcome of privatization. The other reason was that when government sold a big portion of its shares through stock market, many governmental contracts were also disconnected and newly privatized firms faced with many crises. Another reason to blame was associated with the regulation and rules since some people who took part in privatization programs made the payment by some illegal actions. In fact, there were cases where some people purchased only one-third of a privatized company's outstanding shares and changed the management completely. Next, they pushed the governmental banks to get loans and transferred the loans into other firms. As a result, the privatized firm was responsible to pay loan interest and faced with shortage of cash flow.

There were some other cases where government first privatized some firms and then discontinued its support. For instance, the government subsidized the raw material specially in offering raw materials from national mines but when the firm was privatized, the new regulation increased raw materials, substantially, which reduces efficiency.

Recently, there have been some new regulation on energy prices and this could impact the performance of the privatized firms, substantially. This could be a subject of new research and we leave it for interested researchers for future research.

\section{Acknowledgment}

The authors would like to thank the anonymous referees for their comments on earlier version of this paper, which improved the quality of the paper, substantially.

\section{References}

Ahmad, S., \& Schroeder, R.G. (2003). The impact of human resource management practices on operational performance: recognizing country and industry differences. Journal of Operations Management, 21(1), 19-43.

Boubakri, N., \& Bouslimi, L. (2010). Analyst following of privatized firms around the world: The role of institutions and ownership structure. The International Journal of Accounting, 45(4), 413442.

Boubakri, N., Cosset, J.C., \& Saffar, W. (2008). Political connections of newly privatized firms. Journal of Corporate Finance, 14(5), 654-673

Harper, J. T. (2002).The performance of privatized firms in the Czech Republic. Journal of Banking \& Finance, 26(4), 621-649.

Mathur, I., \& Banchuenvijit, W. (2007). The effects of privatization on the performance of newly privatized firms in emerging markets. Emerging Markets Review, 8(2), 134-146. 
Ng, A., Yuce, A., \& Chen, E. (2009). Determinants of state equity ownership, and its effect on value/performance: China's privatized firms. Pacific-Basin Finance Journal, 17(4), 413-443

Omran, M. (2004).The Performance of State-Owned Enterprises and Newly Privatized Firms: Does Privatization Really Matter ? World Development, 32(6), 1019-1041.

Qi, D., Wu, W., \& Zhang, H. (2000). Shareholding structure and corporate performance of partially privatized firms: Evidence from listed Chinese companies. Pacific-Basin Finance Journal, 8(5), 587-610.

Vogel, H.A. (2011). Do privatized airports add financial value ? Research in Transportation Business \& Management, 1(1), 15-24.

Wei, Z., \& Varela,O. (2003). State equity ownership and firm market performance: evidence from China's newly privatized firms. Global Finance Journal, 14(1), 65-82. 